\title{
VALIDATION OF DISCHARGE AND PRESSURE HEAD OF COMPUTER MODEL TO IMPROVE SOLAR WATER PUMPING SYSTEM UNDER EGYPTIAN CLIMATIC CONDITIONS
}

\author{
El-Sayed, A. S. ${ }^{1}$; Hassanain, A. A. ${ }^{2}$; Mosalhi, S. M. ${ }^{3}$ \\ ABSTRACT
}

Multi steps computer program, ISWPS was designed for improving solar pumping systems under Egyptian climatic conditions. Step-7 of the Model was specialized to compute flow rate and head for photovoltaic pumping system under variable intensive solar radiation and high ambient air temperature. This study was carried out to validate the flow rate and generated head with the experimental data at the same incident solar radiation and ambient air temperature. The validation investigated under static head of 0 and $1 \mathrm{~m}$ for both flow rate and generated head. The experimental set-up consists of a stand-alone solar module, a pumping unit comprised a motor and a centrifugal pump (DC-PV pump). The predicted flow rate and water head obtained from ISWPS were validated under the same operating conditions. Statistical Packages for Social Science (SPSS) were used to validate the model with the experimental data (i.e. paired samples statistics, correlations and T-test for paired differences with $99 \%$ confidence interval).

The study revealed that, the computation model estimated the flow rate and the water head especially under intensive solar radiation with an average deviations between measured and predicted flow rates of -3.73 $\%$ and $-0.63 \%$ at static head of $0 \mathrm{~m}$ and $1 \mathrm{~m}$, respectively along six months from July till December. Meanwhile, the average deviations between measured and predicted head for the same period were $-7.78 \%$ and $1.53 \%$ at static head of $0 \mathrm{~m}$ and $1 \mathrm{~m}$, respectively.

\footnotetext{
${ }^{1}$ Prof. of Agr. Eng., Suez-Canal Univ.

${ }^{2}$ Assoc. Prof. of Agr. Eng., Suez-Canal Univ.

${ }^{3}$ Agr. Eng.
}

The $17^{\text {th }}$. Annual Conference of the Misr Society of Ag. Eng., 28 October, $2010 \quad-1836$ - 


\section{INTRODUCTION}

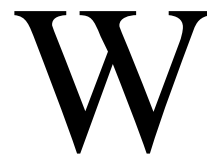

ater pumping processes consumes most energy required for plant production. Solar water pumping composes photovoltaic cells, inverter, electric motors, and pump. Few software programs available, either for commercially use or other, for analyzing photovoltaic water-pumping systems. These small set of programs, in general, had not been validated with experimental data of water-pumping systems Tiba et al., (2002). Hsiao and Blevins, (1984) and, Anis et al., (1984) analyzed the performance of a PV pump theoretically; considering the non-linear behavior of system. Miller and Hittle, (1993) simulated a direct-coupled PV pumping systems by generating a linear correlation of flow rate profile versus solar radiation. Performance of a PV pumps was investigated theoretically under the steady and dynamic state by Anis and Metwally, (1994). A model was proposed by Kou et al. (1998) to predict the direct coupling of photovoltaic pumping system, where the non linear behavior was addressed. The model results were validated with TRNSYS program at differences no more than $6 \%$. Amer and Younes, (2006) estimated the long term performance of photovoltaic water pumping theoretically and experimentally. From experimental measurement, coefficients related to the pump flow rates with the tilted solar radiation were estimated, and then it was used to validate the theoretical model. In the previous experiments carried out by El-Sayed et al., $(2005$ a, b) the flow rate and the head profiles under different incident solar radiation were plotted. Flow rate profile was correlated between tilted solar radiation and pump flow rate, while head profile was expressed as a relationship between the tilted solar radiation and pump total head.

Continuity of research to improve the solar water pumping system in Egypt a multi steps program calls ISWPS was composed and prepared for photovoltaic pumps evaluations. Step-7 of the referred program was specified for computing the pump flow rate and water head, where solar radiation was predicted from step-5.

The objective of the study is to validate step-7 (discharge and pressure head) obtained from ISWPS computer program. The validation was 
carried out experimentally on DC-PV pump (75 Watt) under the prevailing weather conditions of Egypt.

\section{MATERALS AND METHODS}

The validation of experiments was carried out from July till December at the Agricultural Engineering Department of Suez Canal University, Egypt (latitude angle of $31.96^{\circ}$ and longitude angle of $32.38^{\circ}$ ). Measured and predicted flow rates and heads were validated for two water static heads of $0 \mathrm{~m}$ and $1 \mathrm{~m}$. Measurements were carried out from 7:00 am till 17:00 pm, for four days each month (Wednesday of each week) to make fixed time interval between experiments. Measured weather conditions included; the hourly global incident solar radiation on a horizontal and tilted surface stand, ambient air temperature. The pump hydraulic power also was determined using the manometric pressure and the volumetric discharge.

\section{Program algorithm for discharge and head for step-7 of ISWPS} program

Discharge and head were computed in order to determine the performance of photovoltaic pump using ISWPS program; a general procedure was proposed to compute the instantaneous discharge and pressure head for both DC-PV and AC-PV pumps within this model.

The photovoltaic cell temperature $\left(T_{c},{ }^{\circ} \mathrm{C}\right)$ was computed using the following formula (Abou-Hussein et al., 1984):

$$
T_{c}=T_{a}+\left(G / k L_{m}\right)
$$

Where: $\left(T_{a}\right)$ is the ambient temperature, ${ }^{\circ} \mathrm{C},\left(k L_{\mathrm{m}}\right)$ is the module thermal conductivity per the unit of the module length $\left(L_{m}\right.$ in $\left.\mathrm{m}\right), \mathrm{W} \mathrm{m}^{-1}{ }^{\circ} \mathrm{C}^{-1}$ and $(G)$ is the tilted solar radiation in $\mathrm{kWm}^{-2}$, which was computed previously in step-5 within the same computation program. 
The photovoltaic pump water horsepower, $h p,_{w}$ in Watt was computed using the following proposed formula:

$$
\begin{array}{r}
h p,_{w}=\left\{\left(G \times A_{g}\right)+p c\left(\frac{G \times A_{g}}{100}\right) \times\left(25-T_{C}\right)\right\} \times \eta_{P V} \times \\
\eta_{\text {Matching }} \times \eta_{\text {Inverter }} \times \eta_{\text {Motor }} \times \eta_{\text {Pump }}
\end{array}
$$

Where, $A_{g}$, is the photovoltaic generator area in $\mathrm{m}^{2}, p c$ is the power coefficient (the percentage reduction in the power obtained from the module/panel for once Celsius increase, $\% /{ }^{\circ} \mathrm{C}$ ). It was composed in the computation model as $0.45 \% /{ }^{\circ} \mathrm{C}$ as given in Table (2), $\eta_{P V}$ is the nominal efficiency of photovoltaic cells, $\%$, $\eta_{\text {Matching }}$ is the matching efficiency between the photovoltaic generator and subsystem component (depends on the point on the I-V curve of the photovoltaic generator). It is computed either from the actual measurement or from a computation model (Hsiao and Blevins, 1984). $\eta_{\text {Inverter }}$ is the inverter nominal efficiency (considered as $100 \%$, if it is not exist), $\eta_{\text {Motor }}$ is the nominal efficiency of the electric motor, $\%$, and $\eta_{\text {Pump }}$ is the nominal efficiency of the pump \%.

The computation model was fed by an input file relates the discharge of the water pump to the pressure head. This computed file is the ratio between dividing the nominal pump discharge $(q)$, in liter/min by the nominal pump head $(h)$, in $\mathrm{m}$, which is constant with respect to tilted solar radiation (formula, 3 ), where the total head of the pump, $(h)$ was computed as (4):

$$
\begin{gathered}
\frac{q}{h}=\text { Const } \\
h=\left[h p_{w} /(0.1635 \times \text { Const } .)\right]^{0.5}
\end{gathered}
$$

The pump discharge $(q)$ in liter/min was determined from the following proposed formula:

$$
q=h p_{w} /(0.1635 \times h)
$$


The discharge in the computation model is considered if only the generated head equals or greeter than the required head. The hourly discharge was integrated to obtain the daily discharge. For the average day (available option in step-1), it is integrated to obtain the monthly discharge. The month over month are summed to obtain the yearly discharge.

ISWPS simulates the case of water tank if option button titled "Water tank" is clicked as shown in Fig. (1). This case of simulation depends on the left of water from a well or a canal to water cistern and then used in irrigation. Also, ISWPS able to simulate the case of irrigation network if the option button titled "Irrigation network" is clicked but this is not addressed in this study.

\section{Required head}

The required head for the water tank case was computed from:

$$
h_{\text {req,tank }}=\left(h_{d}-h_{s}\right)+\mathrm{v}^{2} /(2 g)
$$

Where: $h_{\text {req,tank }}$ is the required head in case of water tank, $\mathrm{m} ; h_{d}$ is the delivery head, $\mathrm{m} ; h_{s}$ is the suction head, $\mathrm{m}$; $\mathrm{v}$ is the water velocity in the delivery pipe, $\mathrm{m} / \mathrm{sec}$, and $g$ is the acceleration due to gravity, $\mathrm{m} / \mathrm{sec}^{2}$.

Water velocity was obtained from dividing the instantaneous discharge, $\mathrm{m}^{3} / \mathrm{sec}$ by the cross sectional area of the water outlet pipe, $\mathrm{m}^{2}$.

The following three parameters were involved in the model in spite of it was not composed here in this study as it was considered in another study:

1-Rain fall: was taken into consideration of the computation model to make ISWPS more applicable for other locations.

2-Water deficit: considered as the deference between all the input waters and all the output waters at specified cultivated area.

3-Hydraulic losses: referred to the sum of all hydraulic losses started from static left component and ended of emitter/sprinkle pressure requirement. 


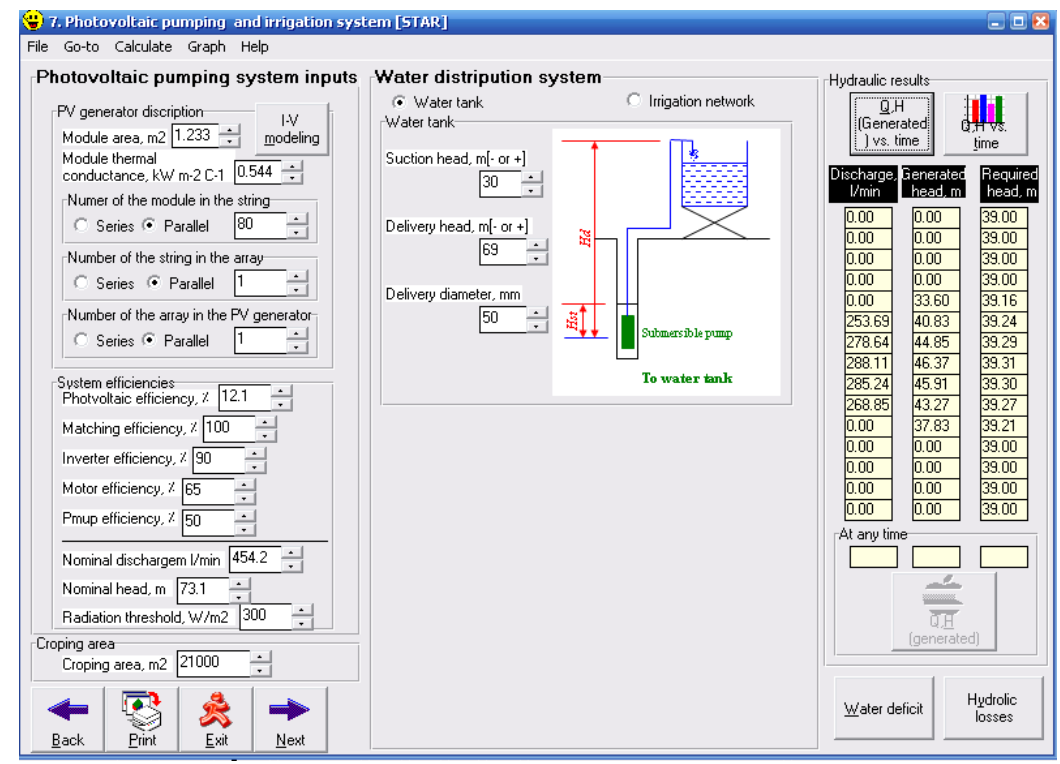

Fig. (1): Graphical user interface for water tank system within step-7

Table (1): The inputs and outputs files used to validate discharge and head

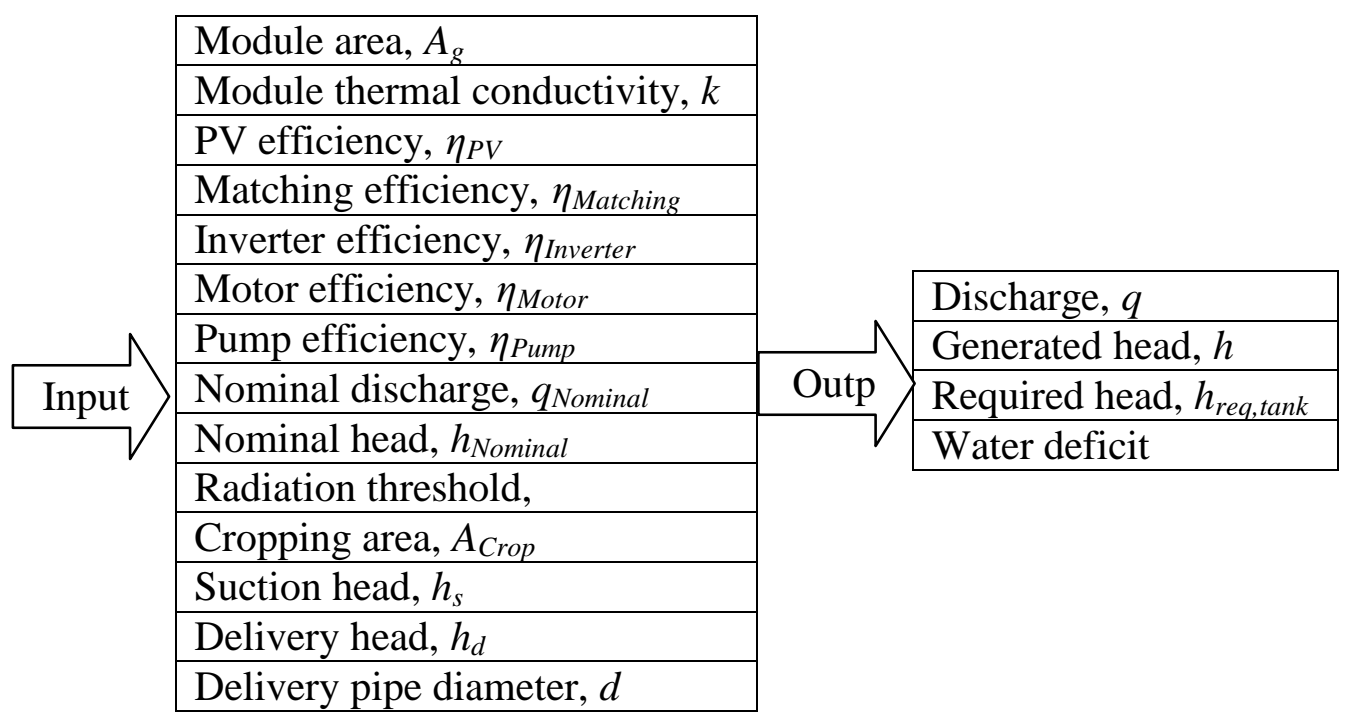

The $17^{\text {th }}$. Annual Conference of the Misr Society of Ag. Eng., 28 October, $2010 \quad-1841-$ 


\section{Experimental set-up}

Set-up for the experimental apparatus is illustrated schematically in Fig. (2); it composed photovoltaic module and motor pump unit. It calls Direct Current Photovoltaic Pump (DC-PV), it can be explained as:

\section{Photovoltaic module}

A stand-alone photovoltaic module with a nominal power of $75 \mathrm{~W}$ was used to carry out the experimental work. The used Siemens module, has the characterizations, presented in Table (2) based on irradiation of 1000 $\mathrm{Wm}^{-2}$, ambient temperature of $25^{\circ} \mathrm{C}$ and 1.5 air mass. The module was mounted on a manual sun-tracking apparatus which was fabricated for this experimental work. The apparatus allows the solar module to rotate vertically and horizontally with one-degree accuracy to fit the solar altitude and solar azimuth angles, at that time the angle of incidence of the surface of the photovoltaic and the sun rays was set at zero.

$\begin{aligned} & \text { Table (2): Characteristics of the used solar module in the } \\
& \text { validation (ASET, 2001) }\end{aligned}$
\begin{tabular}{ll}
\hline Power coefficient & $0.45 \% /{ }^{\circ} \mathrm{C}$ \\
\hline Module area & $0.63 \mathrm{~m}^{2}$ \\
\hline Module thermal conductance, & $0.544 \mathrm{~kW} \mathrm{~m}^{-1}{ }^{\circ} \mathrm{C}^{-1}$ \\
\hline Module efficiency, $\eta_{\mathrm{PV}}$ & $11.8 \%$ \\
\hline
\end{tabular}

\section{Motor-pump unit}

An electrical motor-pumping unit of $50 \mathrm{~W}$ was operated directly from the $75-\mathrm{W}$ solar module. A permanent magnet type motor operates with $24 \mathrm{~V}$ direct electric current was used. A centrifugal pump was used with a suction and delivery diameter of $31.3 \mathrm{~mm}$. The pump has four backward vane type blades. The following table summarized and listed the characteristic of the motor pump.

Table (3): Characteristics of motor pump used in the validation

\begin{tabular}{ll}
\hline Motor efficiency, $\eta_{\text {motor }}$ & $60 \%$ \\
\hline Pump efficiency, $\eta_{\text {pump }}$ & $35 \%$ \\
\hline Nominal discharge & 30.4 liter/min \\
\hline Nominal head & $1.25 \mathrm{~m}$ \\
\hline
\end{tabular}




\section{Measurements}

\section{Incident solar radiation}

Simple Pyranometer apparatus composed a solar cell of 75 x $75 \mathrm{~mm}$ (Kemo, M139, connected to a digital multi-meter (DT830D), was used to measure the incident solar radiation $(G)$ according to Mujahid and Alamoud, (1988) and Duffie and Beckman, (1991). A previously calibration was carried out against Epply Pyranometer before and after the experimental campaign. The short circuit resulted from the cell was measured. Relation between the incident total radiation in $\left(\mathrm{Wm}^{-2}\right)$ and the short circuit current in Ampere was executed and it was used to relate the incident solar radiation.

\section{Temperature measurements}

Temperatures of the ambient air $\left(T_{a}\right),{ }^{\circ} \mathrm{C}$ and solar module surface $\left(T_{c}\right)$, ${ }^{\circ} \mathrm{C}$ were measured by Ama-Digit Ad $15^{\text {th }}$ (electronic thermometer type) which had been calibrated before against previously calibrated mercury, $10: 100^{\circ} \mathrm{C}$ scale thermometer with standard deviation between the thermometers reading of $\pm 0.25^{\circ} \mathrm{C}$.

\section{Volumetric flow rate}

Digital flow meter was used to measure the volumetric flow rate of water (q) using a stopwatch. The accuracy of the flow meter and the stopwatch were $0.0001 \mathrm{~m}^{3}\left(100 \mathrm{~cm}^{3}\right)$ and $1 / 100 \mathrm{sec}$, respectively.

\section{Delivery head}

A piezometer tube of two meters height with one centimeter accuracy was connected to the pump delivery orifice to measure the delivery head $\left(h_{d}\right)$. Tube height was sufficient to measure the delivery heads at the maximum incident solar radiation for the experimental site. Meanwhile, total pressure head was determined according to equation (6). 


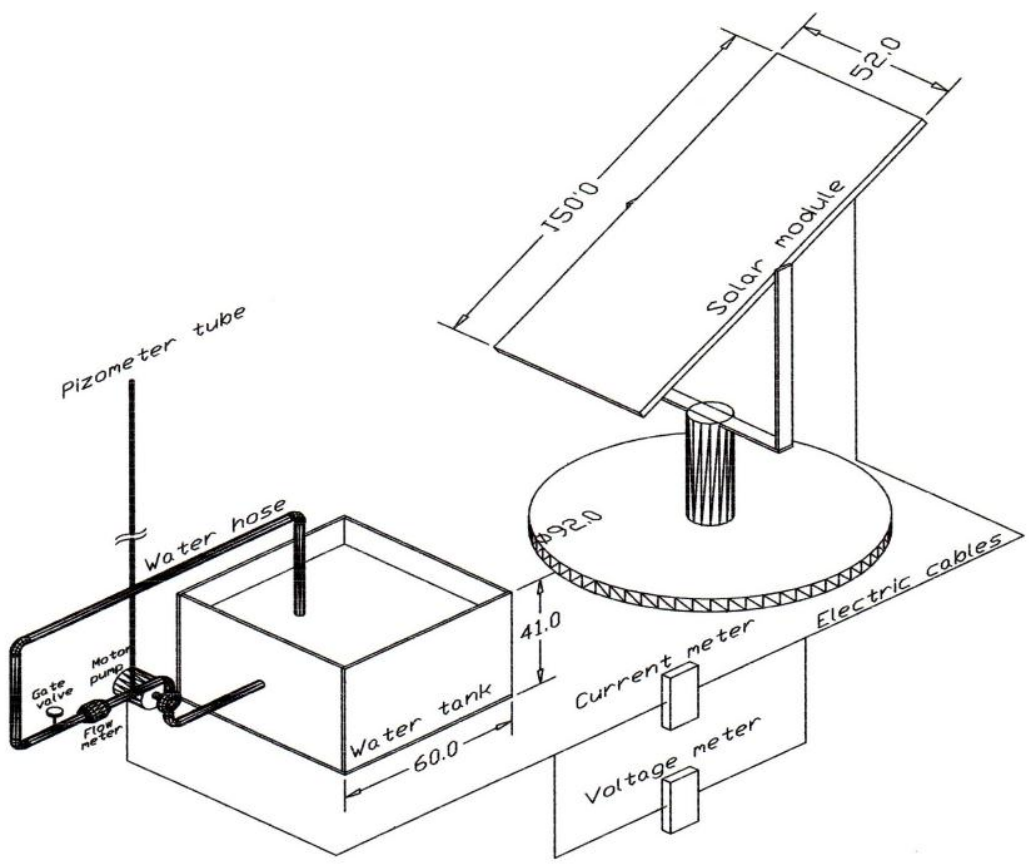

Fig. (2): Schematic diagram of the experimental set-up

\section{Methods and procedures followed}

\section{Statistical tools used in the validation study}

Statistical Packages for Social Science (SPSS), tools were used to characterize and analyze the differences between the predicted and measured parameters as:

1. T test in pairs: this test was used to detect if there is a significant deference between two parameters in pairs (with a variant level of significant 0.01).

2. Deviation percentage: (difference between the measured and the predicted parameters). Deviation was determined according to the following formula:

$$
\text { Deviation, } \%=\frac{\text { measured }- \text { predicted }}{\text { measured }} \times 100
$$

3. Determination coefficient $\left(\mathrm{R}^{2}\right)$ : Determination coefficient was addressed in this study as it indicates the changes in $y$-axis due to that 
in $x$-axis under assumption of independent measured parameter and predicted parameter as a dependent.

\section{RESULTS AND DISCUSSIONS}

\section{Flow rate profile at $0 \mathrm{~m}$ and $1 \mathrm{~m}$ static head}

Measured and predicted flow rate for different solar radiation intensities at $0 \mathrm{~m}$ static head are presented in Fig. (3). The determination coefficients $\left(\mathrm{R}^{2}\right)$ for the best fit curves were 0.89 and 0.84 , respectively. From the figure, four portions of solar radiations affect both of the measured and predicted flow rates:

- Radiation intensity from $0 \mathrm{Wm}^{-2}$ till $233 \mathrm{Wm}^{-2}$ :

There are no flow rates (measured or predicted). The flow rate was found to be equals zero as the pump was not operated. Radiation $233 \mathrm{Wm}^{-2}$ is the measured radiation threshold, which also interred as a required parameter to ISWPS program.

- Radiation intensity from $233 \mathrm{Wm}^{-2}$ till $400 \mathrm{Wm}^{-2}$ :

Overestimate of flow rate was observed in this region. Measured flow rate started at 4.0 liter/min which corresponds predicted of $16.0 \mathrm{liter} / \mathrm{min}$ and the end of this portion of radiation at $20.5 \mathrm{liter} / \mathrm{min}$ for measured and 21.5 liter/min for predicted, respectively.

- Radiation intensity from $400 \mathrm{Wm}^{-2}$ to $900 \mathrm{Wm}^{-2}$ :

Good agreement between measured and predicted flow rate in this radiation range. Within this radiation-band the pump is actually operated with flow rate started at $20.5 \mathrm{liter} / \mathrm{min}$ and $21.5 \mathrm{liter} / \mathrm{min}$ for measured and predicted, respectively, and ended at $32.5 \mathrm{liter} / \mathrm{min}$ and 34.0 liter/min, respectively.

- Radiation intensity above $900 \mathrm{Wm}^{-2}$ :

An overestimate flow rate was observed. This stage stared from the previous stage and ended where the measured flow rate was 31.0 liter/min as it was predicted to be 38.0 liter/min.

Predicted flow rate data was plotted as a function of the measured flow rate as shown in Fig. (4, A and B) for static head of 0 and $1 \mathrm{~m}$, respectively. The best fitting line, at $0 \mathrm{~m}$ static head in Fig. (4A) shows predicted flow rate of 4.9 liter/min corresponds 0 measured flow rate; in another saying (fitting line is not starting from the origin point) as it has inclination angle less than $45^{\circ}$, which refers to the over estimate of 
predicted flow rate at static head of $0 \mathrm{~m}$. For that case, the coefficient of determination $\left(\mathrm{R}^{2}\right)$ was found to be 0.89 and the following equation was obtained:

Where units of the both predicted flow rate, $q_{\text {pre }}$, and measured flow rate $q_{m e s}$ are in liter/min. The slope (0.85) in equation (8) refers to the trend of

$$
q_{\text {pre }}=0.85 \times q_{\text {mes }}+4.97
$$

over-estimate for predicted flow rate over the measured flow rate for static head of $0 \mathrm{~m}$. Meanwhile, flow rate at static head $1 \mathrm{~m}$, which estimates $70 \%$ of the maximum pressure head $(1.42 \mathrm{~m})$. This water head corresponds as incident solar radiation over than $420 \mathrm{Wm}^{-2}$, (which was considered the most solar radiation, which photovoltaic pumps actually are pumping water). An improvement in the quality of prediction at $1 \mathrm{~m}$ static head over that obtained at $0 \mathrm{~m}$ static head was noticed obviously. The coefficient of determination was higher, it was 0.99 compared with 0.88 at $0 \mathrm{~m}$ static head. The linear regression equation relates the relationship between measured and predicted flow rate at $1 \mathrm{~m}$ static head is given in equation (9). The slope (1.01) in the given equation refers to higher prediction of flow rate using ISWPS program at static head of $1 \mathrm{~m}$.

$$
q_{\text {pre }}=1.01 \times q_{\text {mes }}+0.023
$$

Fig. (5, A and B) represent the averages of the percentage deviation of predicted from the measured flow rates determined according to formula (7) within the regular experimental days (22 days as regular measurements each weak along six months from July, 9 to December, 13) at static head of 0 and $1 \mathrm{~m}$, respectively. The following observations were considered from the two figures:

Deviation between the predicted and measured flow rates at $0 \mathrm{~m}$ static head tends to over estimate from summer to winter months, which may be due to the decrease of the collected solar energy by the PV-module. Meanwhile, The estimated flow rate at $1 \mathrm{~m}$ static head was better than at $0 \mathrm{~m}$, this because at static head lower than $1 \mathrm{~m}$, the predicted and measured flow rates were equal zero.

Average deviation for the experimental days was $-3.73 \%$, and $-0.63 \%$ at static head of 0 and $1 \mathrm{~m}$, respectively. This indicates well estimation of the flow rate was achieved using the proposed model. 
In general most of the daily average deviations were not exceed $\pm 8 \%$ and $\pm 5 \%$ at 0 and $1 \mathrm{~m}$ static head, respectively as it is seen in Fig. (5, A and B). The statistics analysis for the measured and predicted flow rates at 0 and $1 \mathrm{~m}$ static heads are represented in Table (4, A, B and C). Pairs sample statistics in Table (4, A) shows an agreement between the measured and predicted flow rates. At 0 static head, the mean, standard deviation, and standard error for measured and predicted flow rates were 29.79 and 30.55 liter/min, 6.58 and 5.98, and 0.46 and 0.42 , respectively. This corresponds 26.67 and 26.84 liter/min, 12.35 and 12.50, and 0.87 and 0.88 for static head of $1 \mathrm{~m}$, respectively.

Table $(4, \mathrm{~B})$ gives paired sample correlations for the flow rate at 0 and $1 \mathrm{~m}$ static head. From the table it is obvious that, the linear correlation between measured and predicted flow rates were as higher-significant as 0.94 and 0.99 for static head of 0 and $1 \mathrm{~m}$, respectively. Meanwhile, Table $(4, \mathrm{C})$ gives $\mathrm{T}$-test for paired sample. The calculated $\mathrm{T}$ was -4.87 , and 2.05 it was less than the tabulated $\mathrm{T}(2.57,1$-tailed) at 0.01 level of significant for 0 and $1 \mathrm{~m}$ static heads, respectively. This indicates no significant difference between the measured and predicted flow rates.

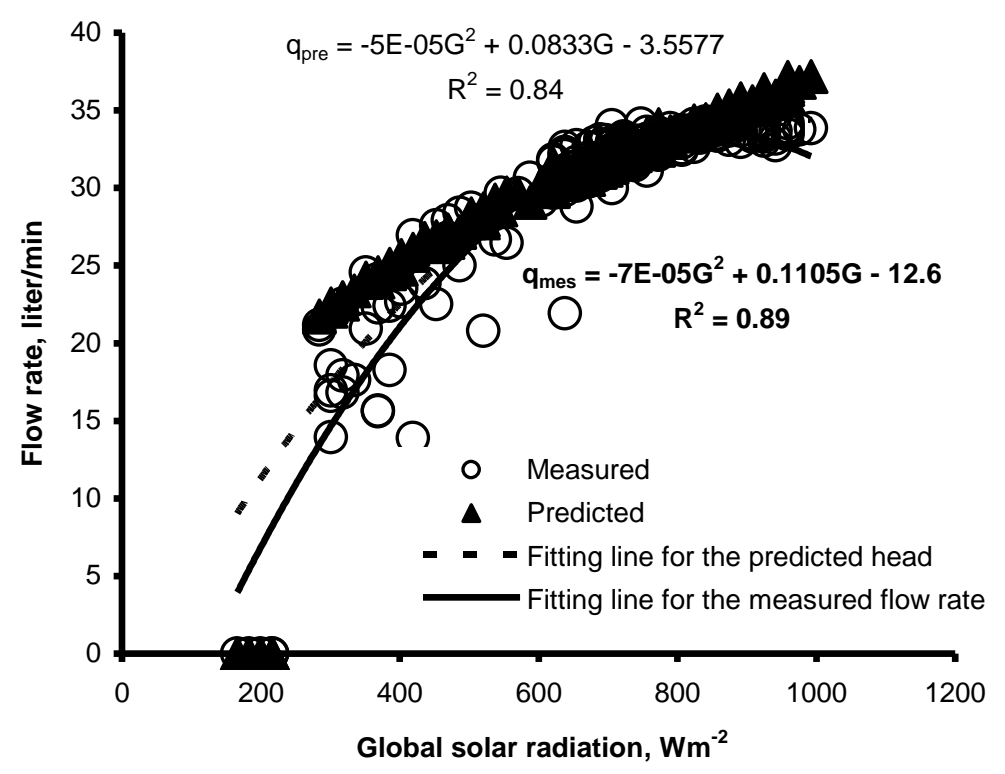

Fig. (3) Measured and predicted flow rate against incident solar radiation for $0 \mathrm{~m}$ static head. 


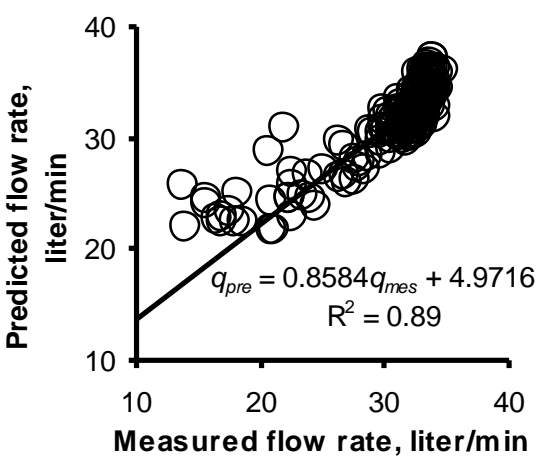

A: Static head of $0 \mathrm{~m}$

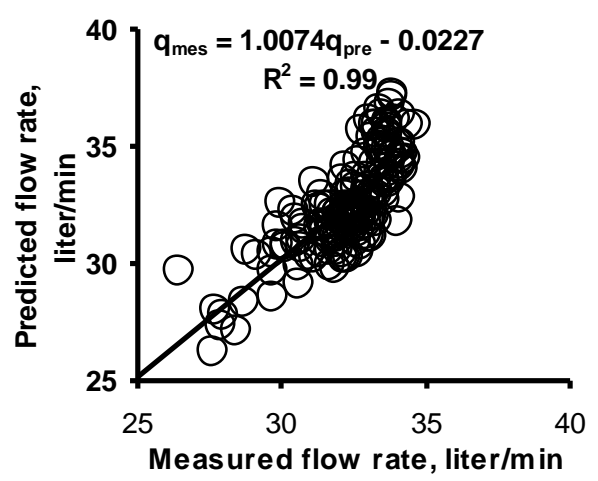

B: Static head of $1 \mathrm{~m}$

Fig. (4): Measured Vs. predicted flow rate at 0and 1m static head

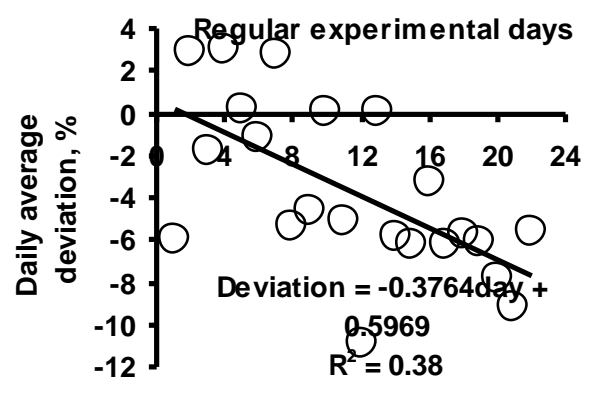

A: Static head of $0 \mathrm{~m}$

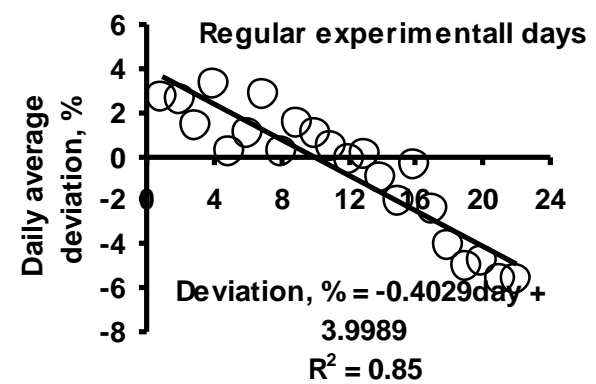

Fig. (5): Percentage deviation from predicted to the measured flow rates against days of investigation

\section{Head profile at $0 \mathrm{~m}$ and $1 \mathrm{~m}$ static head}

Fig. (6) shows the measured and predicted heads for different solar radiation incident on the PV-module. The best fit curves expressed as a second degree poly nominal equation, with coefficients of determination $\left(\mathrm{R}^{2}\right)$ of 0.95 and 0.84 , respectively. From the figure it was noticed that: For the incident solar radiation less than $180 \mathrm{Wm}^{-2}$, the measured and predicted head was found to be $0 \mathrm{~m}$. 
Table (4): Statistic analysis of flow rates at 0 and $1 \mathrm{~m}$ static heads

\begin{tabular}{lccccc}
\multicolumn{1}{l}{ A: paired samples statistics } & \multicolumn{1}{c}{} \\
\hline & \multicolumn{1}{c}{ Mean } & $\mathrm{N}$ & Std. Dev. & Std. Error Mean \\
\hline \multirow{2}{*}{ Static head 0m } & $q_{\text {mea }}$ & 29.79 & 201 & \pm 6.58 & 0.46 \\
\cline { 2 - 6 } & $q_{\text {pre. }}$ & 30.55 & 201 & \pm 5.98 & 0.42 \\
\hline Static head 1m & $q_{\text {mea. }}$ & 26.67 & 201 & \pm 12.35 & 0.87 \\
\cline { 2 - 6 } & $q_{\text {pre }}$ & 26.84 & 201 & \pm 12.50 & 0.88 \\
\hline
\end{tabular}

\begin{tabular}{|c|c|c|c|c|c|c|c|c|}
\hline \multicolumn{9}{|c|}{ B: paired samples correlations between measured and predicted } \\
\hline & $\mathrm{N}$ & Correlation & \multicolumn{2}{|l|}{ Sig. } & & & & \\
\hline Static head $0 \mathrm{~m}$ & 201 & 0.94 & \multicolumn{2}{|l|}{0.00} & & & & \\
\hline Static head $1 \mathrm{~m}$ & 201 & 0.99 & \multicolumn{2}{|l|}{0.00} & & & & \\
\hline \multicolumn{9}{|c|}{ C: paired samples T-Test ( $99 \%$ Confidence Interval of the Difference between $\left.q_{m e s .}-q_{p r e .}\right)$} \\
\hline & \multirow[t]{2}{*}{ Mean } & Std. & Std. Error. & Lower & Upper & $\mathrm{T}$. & D.F. & T.Tab. \\
\hline & & Dev. & Mean & & & Calc. & $(\mathrm{N}-1)$ & \\
\hline Static head $0 \mathrm{~m}$ & -0.75 & \pm 2.19 & 0.15 & -1.16 & -0.35 & -4.87 & 200 & 2.57 \\
\hline Static head $1 \mathrm{~m}$ & -0.17 & \pm 1.20 & 0.08 & -0.39 & 0.05 & -2.05 & 200 & 2.57 \\
\hline
\end{tabular}

Measured head starting at $0 \mathrm{~m}$ water head at $180 \mathrm{Wm}^{-2}$, while the predicted water head is $0.65 \mathrm{~m}$ for the same solar energy intensity.

The difference between the measured and predicted head best fit was decreased till tilted solar radiation intensity of $550 \mathrm{Wm}^{-2}$, where the two best fits are cutoff.

At tilted solar radiation of $980 \mathrm{Wm}^{-2}$ water head was measured $1.42 \mathrm{~m}$, while it predicted as $1.5 \mathrm{~m}$.

For band of incident solar radiation from $450 \mathrm{Wm}^{-2}$ to $980 \mathrm{Wm}^{-2}$, the deviation was less than $\pm 10 \%$.

A relationship between the predicted ( $y$-axis) and the measured head ( $x$ axis) is shown in Fig. (7, A and B) for static heads of 0 and $1 \mathrm{~m}$, respectively. From the figure, it is observed that, at static head of $0 \mathrm{~m}$, the best fit curve for the head started from $0.46 \mathrm{~m}$ and not from the origin point and has inclination angle less than $45^{\circ}$. This refers to the over estimate of predicted head at static head of $1 \mathrm{~m}$, (which was $70 \%$ of the maximum pressure head i.e. $1.42 \mathrm{~m}$ ). This water head corresponds to the tilted solar radiation above $420 \mathrm{Wm}^{-2}$, where the photovoltaic pumps 
actually pumping the water. An improvement in the prediction at $1 \mathrm{~m}$ static head than at $0 \mathrm{~m}$ static head was noticed. The coefficient of determination $\left(\mathrm{R}^{2}\right)$ was 0.81 when the static head was $0 \mathrm{~m}$ and the regression equation was found to be:

$$
h_{\text {pre }}=0.64 \times h_{\text {mes }}+0.46
$$

Meanwhile, the coefficient of determination was 0.99, at static head of $1 \mathrm{~m}$ with the following linear regression equation:

$$
h_{\text {pre }}=0.96 \times h_{\text {mes }}+0.01
$$

Where, the predicted $h_{\text {pre }}$, and measured $h_{\text {mes }}$ heads has the same units (m). The constant (0.64) in equation (10) is the slope of the best fitting curve. This refers to the trend of over estimate of the predicted head over the measured head. Equation (11) of the best fitting curve almost started from the origin point, which indicates high correlation between measured and predicted flow rates using step-7 of ISWPS program at static head of $1 \mathrm{~m}$.

Fig. (8, A and B) shows deviation between the predicted and measured head at static head of 0 and $1 \mathrm{~m}$, respectively. From the figure it can be seen that deviation between the predicted and measured head (for static heads of 0 and $1 \mathrm{~m}$ ) tends to over estimate from summer to winter months, which may be due to the decrease of solar energy received by the PV-module. Average deviation for the regular experimental days was -7.78 and $1.53 \%$ at static head of 0 and $1 \mathrm{~m}$, respectively. In general most of the daily average deviations were not exceed \pm 12 and $\pm 4 \%$ for 0 and $1 \mathrm{~m}$ static head, respectively. This indicates, the model in general was well estimating the daily head.

Table (5, A) represents paired sample statistics for measured and predicted head at 0 and $1 \mathrm{~m}$ statistic heads. From the table, agreement between measured and predicted head was obtained. The mean, standard deviation, and standard error for measured and predicted head were 1.23 and $1.26 \mathrm{~m}, 0.34$ and 0.25 , and 0.02 and 0.02 at $0 \mathrm{~m}$ static head, this corresponds 1.13 and $1.10 \mathrm{~m}, 0.53$ and 0.51 , and 0.04 and 0.04 at $1 \mathrm{~m}$ static head, respectively.

Table (5, B) gives paired sample correlation; from the table it is clear that, the linear correlation between predicted and measured head was as higher significant as 0.90 and 0.99 for static head of 0 and $1 \mathrm{~m}$, 
respectively. Meanwhile, Table $(5, \mathrm{C})$ gives paired sample T-test. The calculated $\mathrm{T}$ was -2.713 , and 2.51 it was less than the tabulated $\mathrm{T}(2.57$, 1-tailed) at 0.01 level of significant for 0 and $1 \mathrm{~m}$ static heads, respectively. This indicates no significant difference between the measured and predicted head.

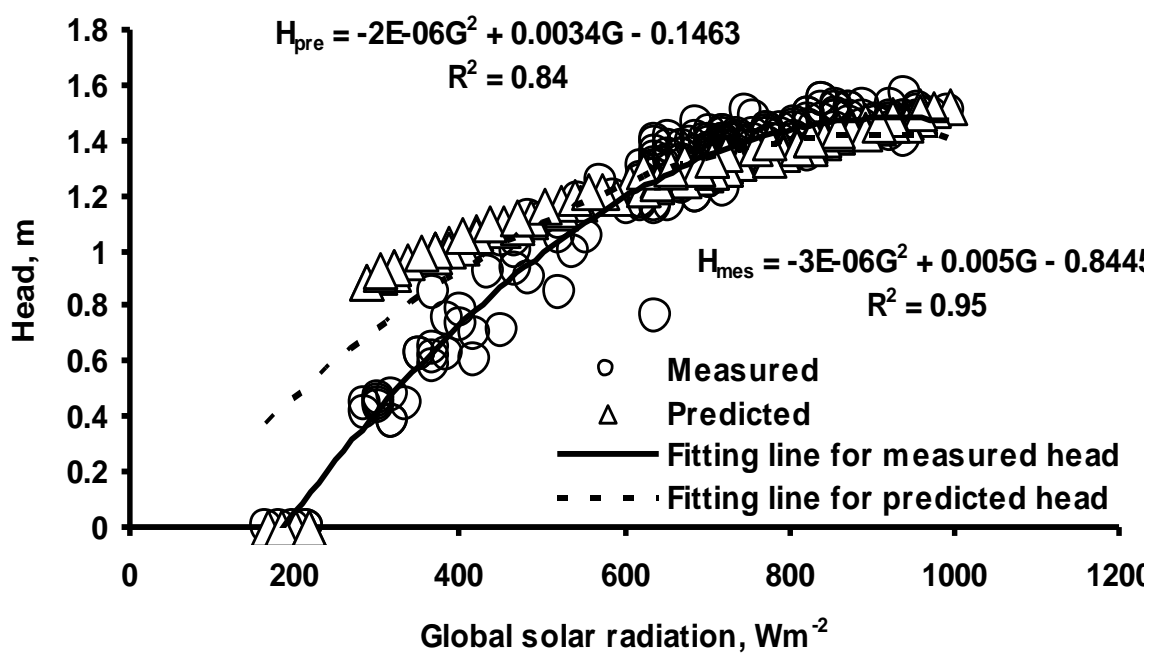

Fig. (6) Measured and predicted head against incident solar radiation for $0 \mathrm{~m}$ static head.

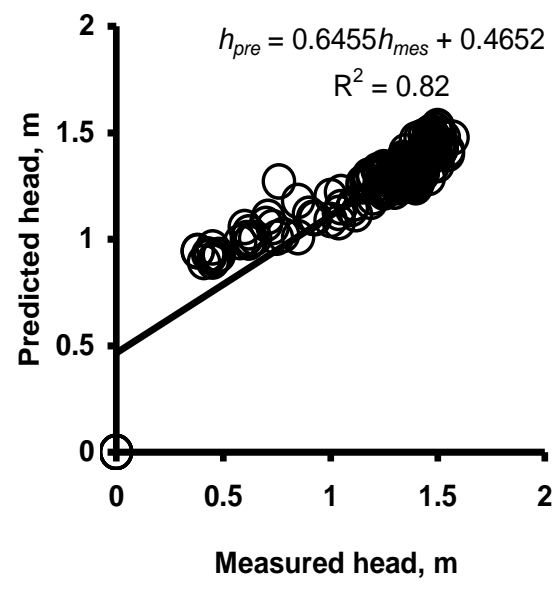

A: $0 \mathrm{~m}$ static head

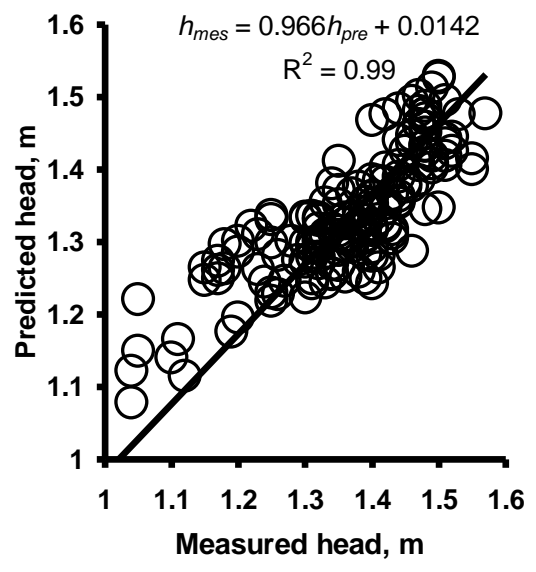

B: 1 m static head

Fig. (7): Measured Vs. predicted head at different static head 

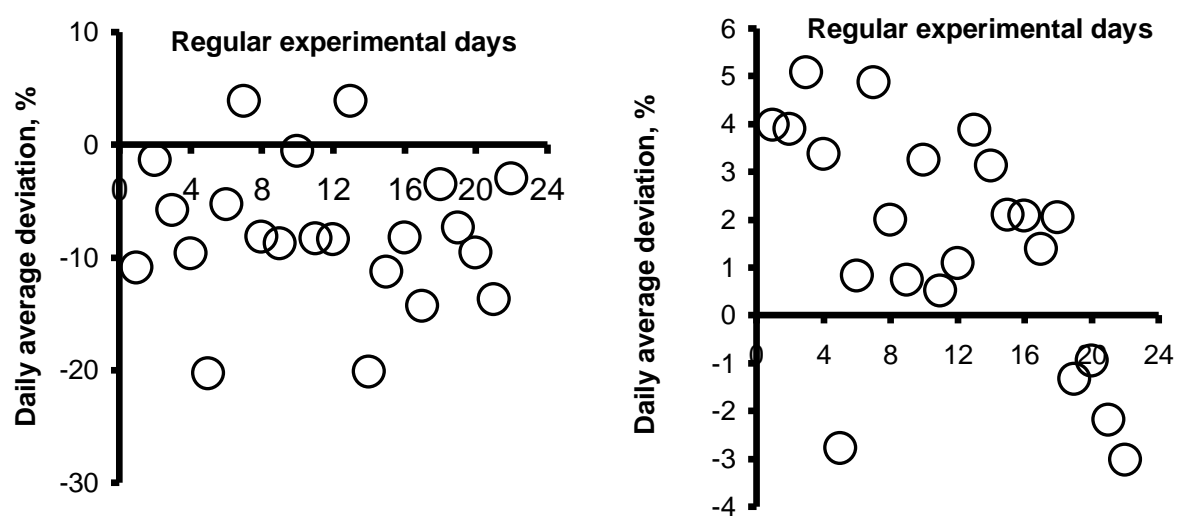
A: Static head of $0 \mathrm{~m}$
B: Static head of $1 \mathrm{~m}$

Fig. (8): Percentage deviation from predicted to the measured head against days of investigation

\section{Table (6): Statistic analysis of heads at 0 and $1 \mathrm{~m}$ static heads}

\begin{tabular}{lccccc}
\multicolumn{7}{c}{ A: paired samples statistics } & \multicolumn{1}{c}{} \\
\hline & \multicolumn{7}{c}{ Mean } & $\mathrm{N}$ & Std. Dev. & Std. Error Mean \\
\hline Static head 0m & $h_{\text {mea. }}$ & 1.23 & 201 & \pm 0.34 & 0.02 \\
\cline { 2 - 6 } & $h_{\text {pre. }}$ & 1.26 & 201 & \pm 0.25 & 0.02 \\
\hline \multirow{2}{*}{ Static head 1m } & $h_{\text {mea. }}$ & 1.13 & 201 & \pm 0.53 & 0.04 \\
\cline { 2 - 6 } & $h_{\text {pre }}$ & 1.10 & 201 & \pm 0.51 & 0.04 \\
\hline
\end{tabular}

B: paired samples correlations between measured and predicted

\begin{tabular}{lccc} 
& N & Correlation & Sig. \\
\hline Static head 0m & 201 & 0.90 & 0.00 \\
\hline Static head 1m & 201 & 0.99 & 0.00 \\
\hline
\end{tabular}

C: paired samples T-Test ( $99 \%$ Confidence Interval of the Difference between $\left.q_{m e s .}-q_{\text {pre. }}\right)$

\begin{tabular}{lllcccccc}
\hline & Mean & $\begin{array}{l}\text { Std. } \\
\text { Dev. }\end{array}$ & $\begin{array}{c}\text { Std. Error. } \\
\text { Mean }\end{array}$ & Lower & Upper & T. & D.F. & T.Tab. \\
\hline Static head 0m & -0.03 & \pm 0.16 & 0.01 & -0.06 & -0.001 & -2.7 & 200 & 2.57 \\
\hline Static head 1m & 0.02 & \pm 0.06 & 0.004 & 0.01 & 0.04 & 2.51 & 200 & 2.57 \\
\hline
\end{tabular}




\section{CONCLUSIONS}

From the present study, the following conclusions can be drown as:

1. The derived computation model was well estimating the flow rate and the water head especially with higher incident radiation as the average deviations between the predicted and measured flow rates during the experimental days (22 days) were $-3.73 \%$ and $-0.63 \%$ at static head of $0 \mathrm{~m}$ and $1 \mathrm{~m}$, respectively. Meanwhile, the average deviations between the predicted and measured head for the same period were $-7.78 \%$ and $1.53 \%$ at static head of $0 \mathrm{~m}$ and $1 \mathrm{~m}$, respectively.

2. Daily average deviations between predicted and measured flow rates were less than $\pm 8 \%$ and $\pm 5 \%$ at static head of $0 \mathrm{~m}$ and $1 \mathrm{~m}$, respectively. Daily average deviations between predicted and measured head were less than $\pm 12 \%$ and $\pm 4 \%$ at static head of $0 \mathrm{~m}$ and $1 \mathrm{~m}$, respectively. This indicates that, the model estimated the daily average head very well.

3. Coefficients of determination $\left(\mathrm{R}^{2}\right)$ were 0.88 and 0.99 between predicted and measured flow rates at $0 \mathrm{~m}$ and $1 \mathrm{~m}$ static head, respectively. It was found to be 0.81 and 0.98 between predicted and measured generated head at $0 \mathrm{~m}$ and $1 \mathrm{~m}$ static head, respectively

4. Based on the T-test, no significant differences between measured and predicted flow rate at $0 \mathrm{~m}$ or $1 \mathrm{~m}$ static head were found; also, no significant differences between measured and predicted generated head at $0 \mathrm{~m}$ or $1 \mathrm{~m}$ static head.

\section{REFERENCES}

Abou-Hussein M. S.; M. H. El-Maghraby; P. P. Groumpos; F. A. ElGeldawy and H. H. El-Tamaly (1984). Techno-economical analysis of different concepts of photovoltaic stand-alone energy systems and application. Solar \& Wind Tec. J., 1(4): 207-221.

Amer, E. H. and M. A. Younes (2006). Estimating the monthly discharge of photovoltaic water pumping system: model verification. Energy Conversion \& Management J., 47: 2092-2102.

Anis, W. R. and H. M. B. Metwally (1994). Dynamic performance of a directly coupled PV pumping system. Solar Energy J., 53: 369-377. 
Anis W.; T. Kerbache; R. Mertens and R. Van Overstraeten (1984). Detailed analysis for photovoltaic powered water pumping system. Solar \& Wind Tec. J., 1(4): 197-205.

ASET $^{\circledR}$, Arabian Solar Energy \& Technology Company (2001). The optimum power in your hand. Product \& Services of Siemens Solar $^{\circledR}$. ASET, Egypt.

Doorenbos, J. (1975). Crop water requirements. Food and Agriculture Organization of the United Nations (FAO), Rome.

Duffie, J. A. and W. A. Beckman, (1991). Solar Engineering of Thermal Process Wiley - Interscine. New York, USA: 3-44.

El-Sayed, A. S.; S. M. Radwan; A. A. Hassanain and S. M. Mosalhi (2005). Weather effect on performance of solar module for water pumping. Misr J. Ag. Eng. 22(3), pp: 874-896.

El-Sayed, A. S.; S. M. Radwan; A. A. Hassanain and S. M. Mosalhi (2005). Effect of orientation and tilt angle on stand-alone solar module performance for simple integrated water pumping system. Misr J. Ag. Eng. 22(3), pp: 944-962.

Hsiao, Y. R. and B. A. Blevins (1984). Direct coupling of photovoltaic power source to water pumping system. Solar Energy J., 32(4): 489-498.

Kou, Q; S. A. Klein and W. A. Beckman (1998). A method for estimating the long-term performance of direct-coupled PV pumping systems. Solar Energy J., 64(1-3): 33-40.

Miller J. A. and D. C. Hittle, (1993). Yearly simulation of a PV pumped, warp-around heat exchanger, solar domestic hot water system. ASME solar engineering proceedings of the ASME international solar energy conference, Washington, D.C., pp: 67-73.

Mujahid, A. M. and A. R. M. Alamoud (1988). An easily designed and constructed photovoltaic Pyrheliometer. Solar \& Wind Tec. J., 5(2): 127-130.

Tiba C.; E. M. and S. Barbosa (2002). Softwares for designing, simulating or providing diagnosis of photovoltaic water-pumping systems. Renewable Energy J., 25: 101-113. 


\section{الملخص العربي : (1)}

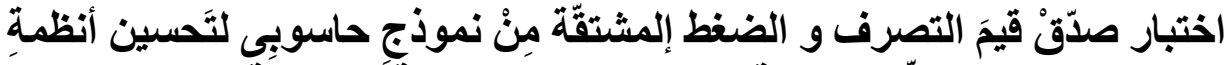

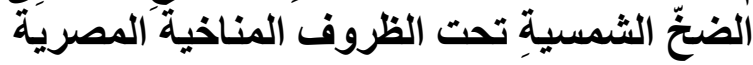

\section{أ.د. عادل سالم السيد، د. أحمد على حسانين و م. السيا محمد مصيلحى}

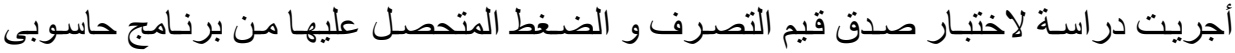
متعدد الخطو ات صمح بلغة الفيجوال بيزيك اطلق عليه ISWPS حيث يقوم البرنـامج بحسـابات

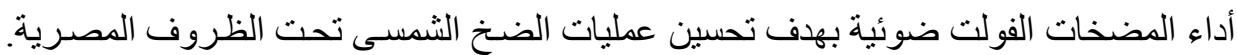

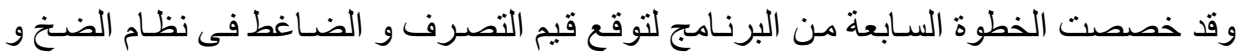

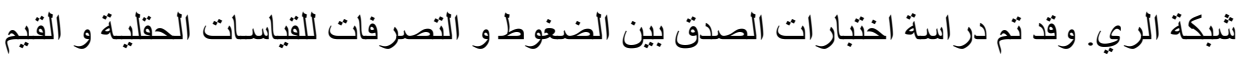

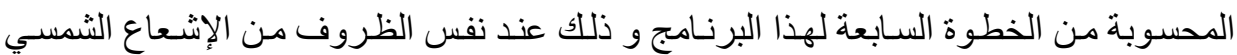

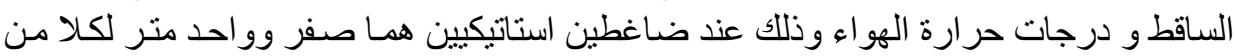
التصرفات و الضغوط المتولدة من المضخة. و توصل البحث إلى النتائج التالية:

ا ـ وجدت الدر اسة أن قيم متوسط النسبة المئويـة للانحر افات بين التصـرفات المقاسـة حقليـا و

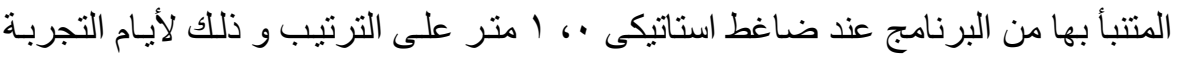

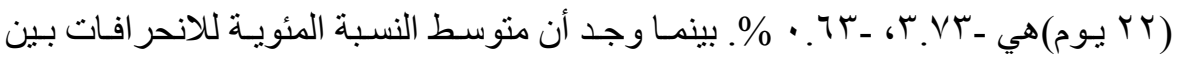

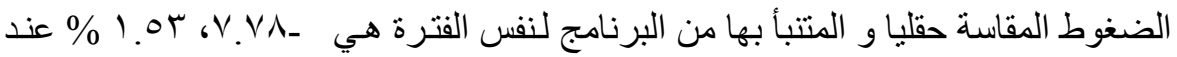

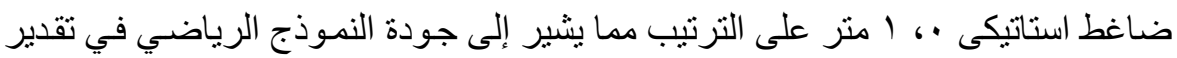

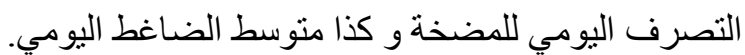

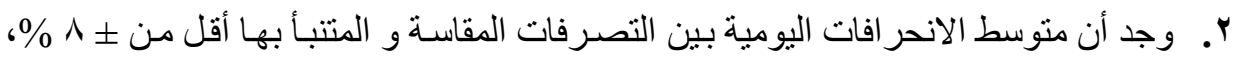

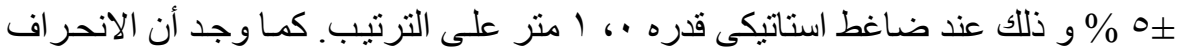

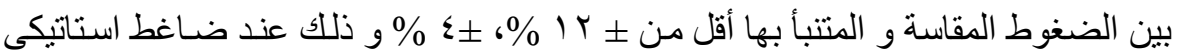

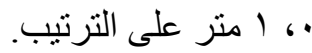

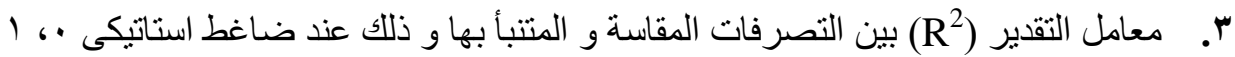

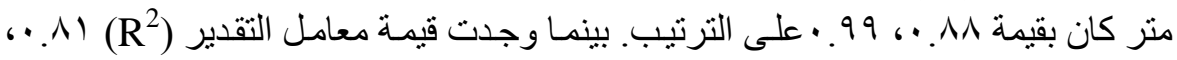

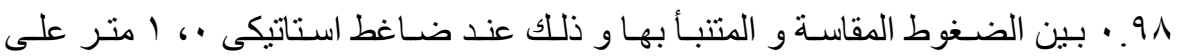
الترنبب. ع. لاتوجد فروق معنوية بين التصرفات المقاسة و المتتبأ بها عند ضاغط استاتيكى · متر أو ا

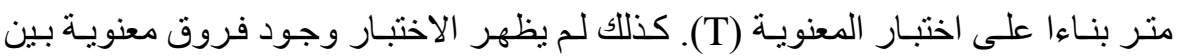
الضغوط المقاسة و المتنبأ بها. على وجه العمـوم، هذا النموذج الرياضـي يقوم بتقدير التصـرفات و الضـغوط المتولدة بصـورة

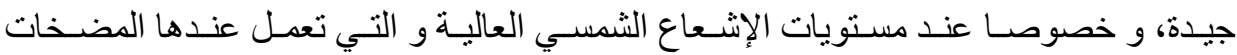

